\title{
Role of Vitamin E on Antispermatogenic Effects of Indomethacin on Number of Sperm Containing Seminiferous Tubules of Testes in Long Evans Rats
}

\author{
Md. Jahangir Alam¹, Monira Khatun², Manowara Begum³ ${ }^{3}$ Muazzem Hossain ${ }^{4}$, Jesmin Akhter ${ }^{5}$, \\ Uttam Kumar Paul ${ }^{6}$, Tahmina Begum ${ }^{7}$
}

\begin{abstract}
Context: Indomethacin is the most commonly and widely used nonsteroidal antiinflammatory analgesic and antipyretic drug. Despite its effectiveness as an antiinflammatory use, indomethacin causes inhibition of spermatogenesis leading to infertility. On the other hand, vitamin E enhances spermatogenesis. Therefore, the present study was designed to observe the protective role of vitamin $E$ on indomethacin induced testicular damage.
\end{abstract}

Objective: To observe the effects of vitamin E on indomethacin induced testicular damage in Long Evans rats.

Study design: An experimental study.

Place and period of study: The study was carried out in the Department of Anatomy, Sir Salimullah Medical College, Dhaka.

Materials and methods: Eightyfour mature Long Evans male rats were divided into four groups (I, II, III and IV). The rats of group I, II and III were treated with indomethacin at different doses and duration. Group IV rats were treated with indomethacin and vitamin $E$ at different doses for 49 days. Histologically the number of sperm containing and nonsperm containing seminiferous tubules were counted.

Results: There was significant reduction $(P<0.001)$ in number of sperm containing seminiferous tubules when the rats were treated with indomethacin at low ( $2 \mathrm{mg} / \mathrm{kg}$ body wt/day) and high dose (10 $\mathrm{mg} / \mathrm{kg}$ body wt/day) for 7, 14 and 42 days, respectively. On the other hand, rats treated with indomethacin and vitamin $E$ for 49 days showed increase in number of sperm containing seminiferous tubules compared to the other groups $(P<0.001)$.

Conclusion: It can be concluded from this study that vitamin $E$ has potential role in the prevention of the antispermatogenic effects of indomethacin.

Key words: Seminiferous tubules, Indomethacin, Vitamin E

\section{Introduction}

Indomethacin is the most commonly and widely used nonsteroidal antiinflammatory, analgesic and antipyretic drug. It was first introduced in 1963 for

1. Assistant Professor (c.c.), Department of Anatomy, Sir Salimullah Medical College, Dhaka

2. Associate Professor, Department of Anatomy, Dhaka Medical College, Dhaka

3. Professor, Dept. of Anatomy, Dhaka Medical College, Dhaka

4. Assistant Professor, Enam Medical College, Savar

5. Assistant Professor, Ibrahim Medical College, Dhaka

6. Assistant Professor, Department of Anatomy, Sir Salimullah Medical College, Dhaka

7. Lecturer, Department of Anatomy, Sir Salimullah Medical College, Dhaka

Correspondance: Dr. Md. Jahangir Alam the treatment of rheumatoid arthritis and related disorders ${ }^{1}$. Patients receiving the therapeutic dose of indomethacin suffered from gastrointestinal upset, abdominal pain, peptic ulcer, with bleeding and perforation, also mental confusion, depression and psycosis $^{1}$. Despite its effectiveness as an antiinflammatory drug, toxic effect to testes have significantly restricted its use.

Within each testis, there are almost 200 million of seminiferous tubules, and th ese structures account for $8090 \%$ of the testicular mass ${ }^{2}$. The germinal epithelium of seminiferous tubules of the testis is one of the most proliferating tissue in the body capable of producing millions of spermatozoa every 
hour $^{3,4}$. Oligospermia and azoospermia have been reported after the use of indomethacin ${ }^{5}$. Indomethacin causes inhibition of spermatogenesis by inhibition of prostaglandin synthesis leading to infertility in human being 6 . On the other hand, vitamin $E$ is a fat soluble vitamin. It enhances spermatogenesis by inhibition of lipid peroxidation and lowers the incidence of abnormal sperm production ${ }^{7,8}$. Therefore, the present study was designed to observe the protective role of vitamin $\mathrm{E}$ on indomethacin induced testicular damage.

\section{Materials and Methods}

Eightyfour mature Long Evans male rats, 2.5 to 3.5 months old, weighing 200300 gms were included in this study.

Drugs: The following drugs were used in the present study:

1) Indomethacin powder: (a) Low dose $2 \mathrm{mg} / \mathrm{kg}$ body weight/day, (b) High dose $10 \mathrm{mg} / \mathrm{kg}$ body weight/day. Indomethacin suspensions were made in distilled water and administered intragastrically ${ }^{5,6}$.

2) Vitamin $\mathrm{E}$ powder, dose $100 \mathrm{mg} / \mathrm{kg}$ body weight/day. Suspensions of vitamin E were made by mixing it with a vehicle and administered intragastrically ${ }^{8}$.

3) Vehicle: Distilled water for control group, dose $2 \mathrm{ml} / \mathrm{rat} /$ day.

\section{Methods}

Eightyfour male rats were divided into four main groups (I, II, III and IV). These main groups were again divided in subgroups a (control), b (2 mg indomethacin/kg body wt/day) and c (10 mg/kg body $\mathrm{wt} /$ day) on the basis of the dose of indomethacin. Each subgroup contained 7 rats. Grouping of animals and their treatment were done on the basis of duration of treatment ${ }^{9}$.

Rats of group I, II and III were treated by indomethacin at low and high doses for 7, 14 and 42 days respectively. Group IV rats were treated with indomethacin and vitamin $E$ for 49 days.

Principally assigning seminiferous tubules as 'spermatogenic' or 'non spermatogenic' in histological section assessed the damaging effect of testes ${ }^{10}$. For this, 6 micron thick paraffin sections were prepared from $4 \mathrm{~mm}$ thick tissue blocks and transverse to the longitudinal axis of testes fixed in $10 \%$ formol saline and were stained with hematoxyline and eosin. The number of round or oval seminiferous tubular cross sections were then estimated separately in 7 good testicular sections from 7 different rats of each group, and the percentage of round tubules that exhibited spermatogenesis was calculated. For this estimation, the tissue section on the slide was divided into four quadrants on a counting circle printed on a transparent sheet placed inside the eyepiece to superimpose in turn of the four quadrants close to where the four quadrants met (Fig.-1). The microscopic field inside the circle (under X40 objective, $x 10$ eyepiece) was then examined to count the tubules that were completely within the circle and were circular or oval in shape and categorize them as spermatogenic or nonspermatogenic (Fig.-1). Spermatogenesis was considered to be present if at least three spermatogonia (not sertoli cells) were seen on the tubule wall in close proximity. It was found that a proportion (6.39\%) of tubule cross sections in the normal control group was completely devoid of spermatogenic elements and contained only sertoli cells. A correction for the 'background' was applied in the indomethacin treated groups and thus the proportion of tubules exhibiting spermatogenesis was calculated from $\mathrm{N} /[\mathrm{T}$ (T.P)] (where $\mathrm{N}$ equals the number of cross sections with spermatogenic cells, $T$ equals the total number of cross sections counted, and $\mathrm{P}$ equals the proportion of the total which was assumed to be devoid of cells at the time of treatment $)^{11}$.

For statistical analysis, the data obtained from different groups of rats were analysed and comparisons made using Student's 't' test.

\section{Results}

There was significant reduction $(P<0.001)$ in number of sperm containing seminiferous tubules when the rats were treated with indomethacin at low $(2 \mathrm{mg} /$ $\mathrm{kg}$ body weight/day) and high dose (10 $\mathrm{mg} / \mathrm{kg}$ body weight/day) for 7,14 and 42 days, respectively. On the other hand, rats treated with indomethacin and vitamin $E$ for 49 days showed significant increase $(P<0.001)$ in number of sperm containing seminiferous tubules compared to control and other groups (Table-I \& Fig. 3,4,5). 
Bangladesh J. Anat. 2009; 7(1) : 5-9

Table-I

Effect of indomethacin/indomethacin plus vitamin E on number of sperm and nonsperm containing tubules of different groups of rats

\begin{tabular}{|c|c|c|c|c|c|c|}
\hline \multirow[b]{3}{*}{ Groups } & \multirow{3}{*}{$\begin{array}{l}\text { Duration of } \\
\text { treatment } \\
\text { (days) }\end{array}$} & \multirow{3}{*}{ 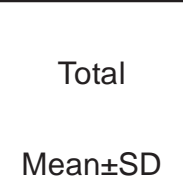 } & \multicolumn{4}{|c|}{ Number of tubules/high power field (X40) } \\
\hline & & & \multicolumn{2}{|c|}{ Sperm containing } & \multicolumn{2}{|c|}{ Nonsperm containing } \\
\hline & & & Mean $\pm S D$ & Percent & Mean $\pm S D$ & Percent \\
\hline la & 7 & $\begin{array}{c}19.14 \pm 1.46 \\
(18.022 .0)\end{array}$ & $\begin{array}{c}17.92 \pm 1.37 \\
(16.8520 .59)\end{array}$ & 93.61 & $\begin{array}{c}1.22 \pm 0.10 \\
(1.151 .41)\end{array}$ & 6.39 \\
\hline Ib & 7 & $\begin{array}{l}22.86 \pm 5.64 \\
(14.031 .0)\end{array}$ & $\begin{array}{c}19.25 \pm 5.23 \\
(11.1127 .02)\end{array}$ & 83.75 & $\begin{array}{c}3.60 \pm 0.56 \\
(2.894 .59)\end{array}$ & 16.25 \\
\hline Ic & 7 & $\begin{array}{c}29.14 \pm 5.08 \\
(24.036 .0)\end{array}$ & $\begin{array}{c}21.57 \pm 3.00 \\
(18.4725 .70)\end{array}$ & 74.47 & $\begin{array}{c}7.57 \pm 2.44 \\
(5.3310 .30)\end{array}$ & 25.53 \\
\hline Ila & 14 & $\begin{array}{l}22.71 \pm 2.87 \\
(19.027 .0)\end{array}$ & $\begin{array}{c}21.26 \pm 2.68 \\
(1.7925 .27)\end{array}$ & 93.61 & $\begin{array}{c}1.45 \pm 0.19 \\
(1.211 .73)\end{array}$ & 6.39 \\
\hline $\mathrm{Ilb}$ & 14 & $\begin{array}{c}21.14 \pm 3.24 \\
(16.025 .0)\end{array}$ & $\begin{array}{c}15.65 \pm 3.16 \\
(10.9819 .41)\end{array}$ & 73.53 & $\begin{array}{c}5.50 \pm 0.38 \\
(5.026 .21)\end{array}$ & 26.47 \\
\hline Ilc & 14 & $\begin{array}{l}27.71 \pm 5.82 \\
(20.036 .0)\end{array}$ & $\begin{array}{c}12.77 \pm 0.37 \\
(12.2813 .30)\end{array}$ & 47.58 & $\begin{array}{l}14.94 \pm 5.45 \\
(7.7222 .70)\end{array}$ & 52.42 \\
\hline IIIa & 42 & $\begin{array}{c}18.14 \pm 0.90 \\
(17.019 .0)\end{array}$ & $\begin{array}{c}16.99 \pm 0.84 \\
(15.9217 .79)\end{array}$ & 93.63 & $\begin{array}{c}1.16 \pm 0.06 \\
(1.081 .21)\end{array}$ & 6.37 \\
\hline IIIb & 42 & $\begin{array}{c}26.43 \pm 6.16 \\
(18.034 .0)\end{array}$ & $\begin{array}{c}17.18 \pm 4.01 \\
(10.9121 .83)\end{array}$ & 65.83 & $\begin{array}{c}9.25 \pm 4.03 \\
(1.2812 .17)\end{array}$ & 34.17 \\
\hline IIIC & 42 & $\begin{array}{c}30.00 \pm 6.29 \\
(24.039 .0)\end{array}$ & $\begin{array}{c}1.92 \pm 0.40 \\
(1.532 .49)\end{array}$ & 6.39 & $\begin{array}{c}28.08 \pm 5.89 \\
(22.4736 .51)\end{array}$ & 93.61 \\
\hline IVa & 49 & $\begin{array}{c}16.00 \pm 2.08 \\
(13.019 .0)\end{array}$ & $\begin{array}{c}14.98 \pm 1.95 \\
(12.1717 .79)\end{array}$ & 93.62 & $\begin{array}{c}1.02 \pm 0.13 \\
(0.831 .21)\end{array}$ & 6.38 \\
\hline $\mathrm{IVb}$ & 49 & $\begin{array}{c}24.86 \pm 5.34 \\
(19.033 .0)\end{array}$ & $\begin{array}{c}21.27 \pm 5.00 \\
(15.7928 .89)\end{array}$ & 85.26 & $\begin{array}{c}3.59 \pm 0.34 \\
(3.214 .11)\end{array}$ & 14.74 \\
\hline IVc & 49 & $\begin{array}{c}20.86 \pm 1.35 \\
(19.023 .0)\end{array}$ & $\begin{array}{c}16.10 \pm 1.32 \\
(14.7218 .53)\end{array}$ & 77.13 & $\begin{array}{c}4.76 \pm 0.55 \\
(4.215 .41)\end{array}$ & 22.87 \\
\hline la vs Ib & 7 & $>0.10^{\mathrm{ns}}$ & $>0.50^{\mathrm{ns}}$ & & $<0.001^{\star \star \star}$ & \\
\hline la vs Ic & 7 & $<0.001^{\star \star \star}$ & $<0.05^{*}$ & & $<0.001^{\star \star \star}$ & \\
\hline Ib vs Ic & 7 & $<0.05^{\star}$ & $>0.10^{\mathrm{ns}}$ & & $<0.001^{\star \star \star}$ & \\
\hline Ila vs IIb & 14 & $>0.10^{\mathrm{ns}}$ & $<0.01^{\star *}$ & & $<0.001^{\star \star \star}$ & \\
\hline Ila vs IIc & 14 & $>0.05^{\mathrm{ns}}$ & $<0.001^{\star * *}$ & & $<0.001^{\star \star \star}$ & \\
\hline IIb vs IIc & 14 & $<0.05^{\star}$ & $<0.05^{\star}$ & & $<0.001^{\star \star \star}$ & \\
\hline IIla vs IIIb & 42 & $<0.01^{\star \star}$ & $>0.50^{\mathrm{ns}}$ & & $<0.001^{\star \star *}$ & \\
\hline IIla vs IIIc & 42 & $<0.001^{\star * \star}$ & $<0.001^{\star * *}$ & & $<0.001^{\star \star \star}$ & \\
\hline IIIb vs IIIc & 42 & $>0.10^{\mathrm{ns}}$ & $<0.001^{\star * \star}$ & & $<0.001^{\star \star \star}$ & \\
\hline IVa vs IVb & 49 & $<0.001^{* * *}$ & $<0.01^{* *}$ & & $<0.001^{\star * *}$ & \\
\hline IVa vs IVc & 49 & $<0.001^{* * *}$ & $>0.10^{\mathrm{ns}}$ & & $<0.001^{\star * \star}$ & \\
\hline IVb vs IVc & 49 & $>0.05^{\mathrm{ns}}$ & $<0.05^{*}$ & & $<0.001^{* * \star}$ & \\
\hline Illb vs IVb & & $>0.50^{\mathrm{ns}}$ & $>0.50^{\mathrm{ns}}$ & & $<0.01^{\star *}$ & \\
\hline IIIc vs IVc & & $>0.10^{\mathrm{ns}}$ & $<0.001^{\star \star \star}$ & & $<0.001^{\star \star \star}$ & \\
\hline
\end{tabular}

Figures in parentheses indicate range. Comparison between groups done by Unpaired Student's 't' test, ns =

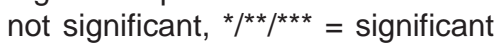




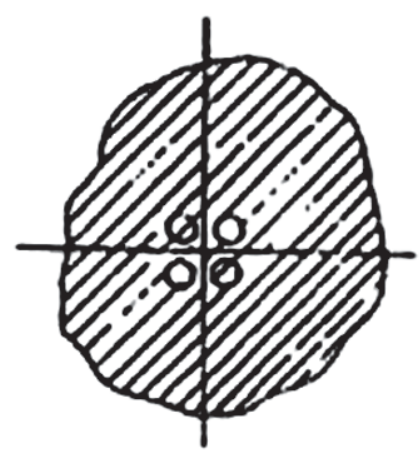

Fig.-1. Outline of the microscopic field and of the superimposed counting circle

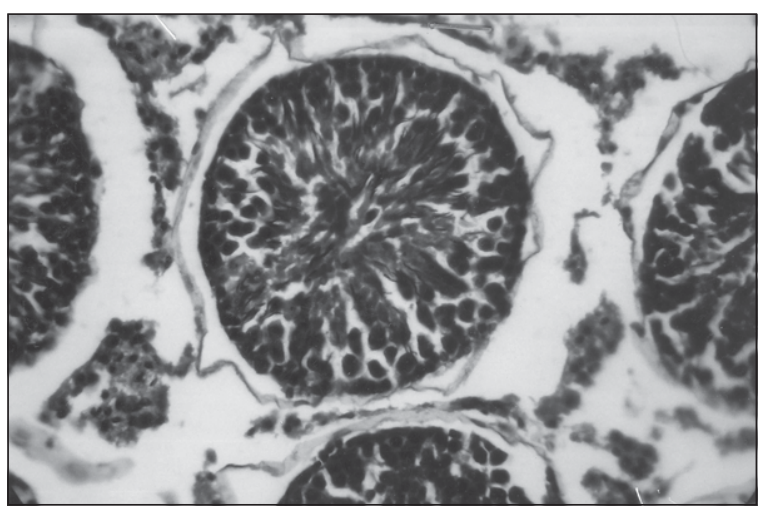

Fig.-3. A high power (X40 objective) photomicrograph of a section of rat testis of control group showing seminiferous tubules with normal spermatogenesis [H\&E stain].

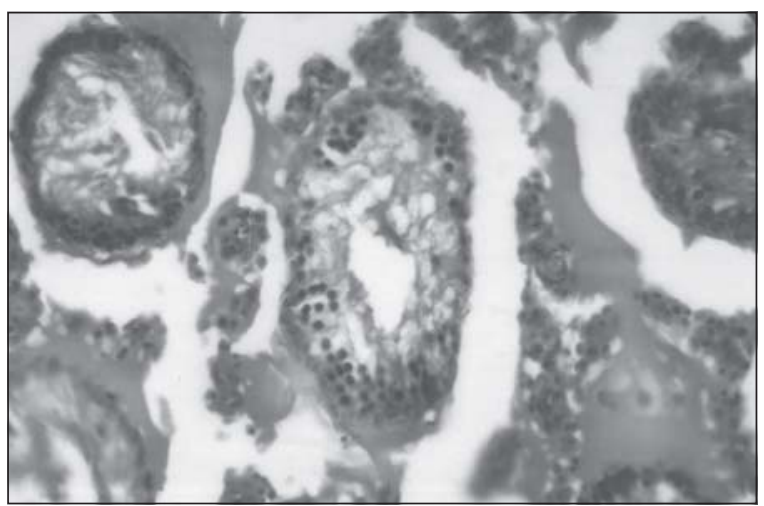

Fig. 5. A high power (X40 objective) photomicrograph of a section of rat testis of experimental group following 49 days treatment with indomethacin plus vitamin $E$ showing germinal epithelum preserved in most of seminiferous tubules [H\&E stain].

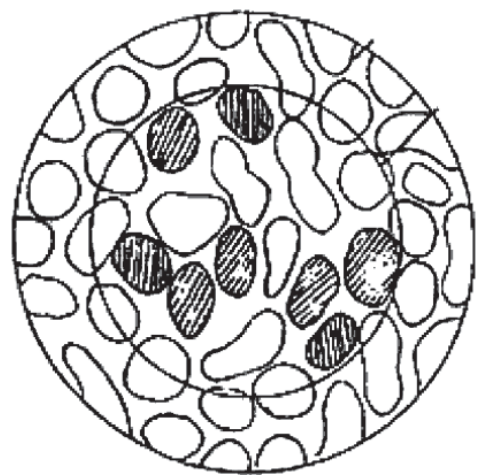

Fig.-2. Procedure of counting spermatogenic and nonspermatogenic seminiferous tubules

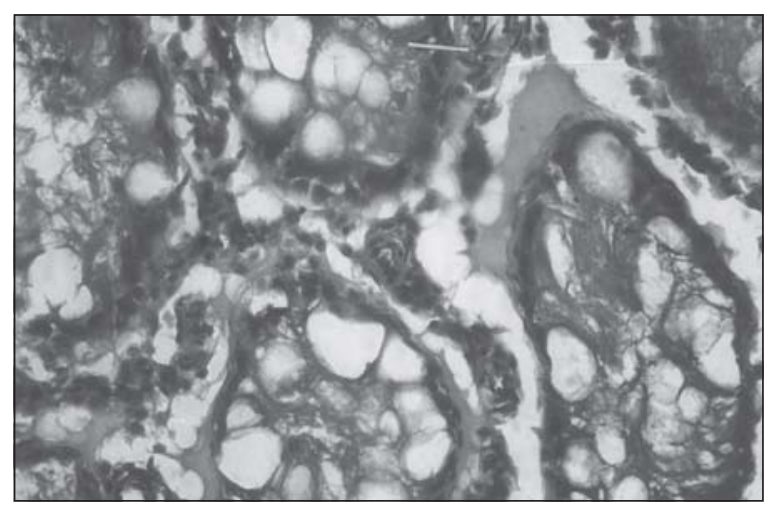

Fig.-4. A high power (X40 objective) photomicrograph of a section of rat testis of experimental group showing seminiferous tubules devoid of germinal epithelium following 42 days treatment with indomethacin [H\&E stain).

\section{Discussion}

The number of sperm containing seminiferous tubules of all indomethacin treated rats were reduced. The reduction in the number of sperm containing seminiferous tubules were highly significant $(P<0.001)$ in the rats treated with indomethacin at low and high doses for longer duration (14 and 42 days).

Similar findings were also observed by Balasubramanian et al. ${ }^{6}$, Kumar and Chinoy ${ }^{9}$ and $\mathrm{Ara}^{12}$. The reduction in number of spermatogenic tubules may be due to the loss of germinal elements.

The number of sperm containing seminiferous tubules increased markedly and was highly significant $(P<0.001)$ in vitamin $E$ treated rats in 
comparison to control group and also to indomethacin treated group of rats. This result was similar to the results observed by Cooper and Carpenter ${ }^{7}$, Mishra and Acharya ${ }^{8}$.

\section{References}

1. Robert LJ, Morrow JD. Analgesic antipyretics and antiinflammatory agents and drugs employed in the treatment of gout. In: Limbird LE, Hardman JG. editors. Goodman and Gilman's: the pharmacological basis of therapeutics. 10th ed. New York: McGraw Hill Companies, 2001: p.687 731.

2. Greenspan FS, Gardner DG. Basic and clinical endocrinology. 6th ed. New York: McGraw Hill Companies, 2001: p.422 8.

3. Guyton AC, Hall JE. Textbook of medical physiology. 10th ed. Philadelphia: WB Saunders Company, 2002: p.916 28.

4. Ganong WF. Review of medical physiology. 21st ed. New York: McGraw Hill Companies, 2003: p.428 37.

5. Loscher W, Blazaki D. Effect of nonsteroidal antiinflammatory drugs on fertility of male rats. J Reprod Fert 1986; 76:65 73.
6. Balasubramanian A, Manimekalai S, Guna Singh A, Rama Krishnan S. Short and long term effect of aspirin on testes of albino rats. Indian J Expl Biol 1980; 18:1408 10.

7. Cooper DR, Carpenter MP. Sertoli cell prostaglandin synthesis: effects of (follitropin) differentiation and dietary vitamin E. Biochem J 1987; 241:847 55.

8. Mishra M, Acharya UR. Protective effect of vitamin $\mathrm{E}$ on spermatogenesis in lead treated Swiss mice. Med J Biol Trace Elem 2004; 18:1738.

9. Kumar RA, Chinoy NJ. Effects of acetyl salicylic acid on reproductive organs of adolescent male rats. J Endocrin Expl 1988; 22:187 95

10. Withers HR, Hunter N, Barkley HT, Reid BO. Radiation survival and regeneration characteristics of spermatogenic stem cells of mouse testis. Radiat Res 1974; 57:88 103.

11. Delic JI, Bush C, Peckam MJ. Protection from procarbazine induced damage of spermatogenesis in the rat by androgen. Cancer Res 1986; 46:1909 14.

12. Ara S. Histomorphological changes in testes induced by aspirin and its prevention by prostaglandins in rat [thesis]. Dhaka: University of Dhaka, 1992. 